\title{
The habitat of the water vole Arvicola sapidus Miller, 1908 in France: description and conservation
}

\author{
El hábitat de la rata de agua Arvicola sapidus Miller, \\ 1908 en Francia: descripción y conservación \\ Arvicola sapidus Miller, 1908 mendebaldeko \\ ur-arratoiaren habitata Frantzian: deskribapena eta kontserbazioa
}

\begin{abstract}
Pierre Rigaux ${ }^{1 *}$
${ }^{1}$ Société Française pour l'Etude et la Protection des Mammifères (SFEPM).

*Corresponding author: prl.rigaux@laposte.net
\end{abstract}

\begin{abstract}
The water vole Arvicola sapidus Miller, 1908 is a semi-aquatic species found in both Spain and France. It is highly probable that the water vole will experience a significant decline throughout a large part of its range of distribution. The preservation of its habitat is an important issue for its conservation in France. Numerous surveys have been carried out over several years providing enough information about the typical habitat of the water vole in France, and enabling us to make some general recommendations in support of its conservation. The water vole can be found in diverse aquatic areas yet always with certain characteristics in common. In the main, common features include the facies of the river substrate and its vegetation. Ground vegetation is typically herbaceous, generally hygrophilous, and above all sufficiently tall so that the water voles can move without being seen. Ideal environments are more often those that are not long-lasting on the river network. These places are at times unstable due to natural or human disturbance. The local distribution of these micro-habitats, their evolution and their connection conditions effect, to a great extent, the local distribution of the species as well as their presence across the network of sites. A great deal of the French countryside, particularly in rural areas, is maintained and the state of these areas depends heavily on human use. The conservation of the water vole in these areas completely depends on maintaining these sites as suitable habitats for this species.
\end{abstract}

KEY WORDS: Bank management, blue corridor, semi-aquatic mammals, water network.

\section{RESUMEN}

La rata de agua Arvicola sapidus Miller, 1908 es un roedor semiacuático que se distribuye por España y Francia. Es probable que esté experimentando un importante descenso a lo largo de gran parte de su área de distribución. El mantenimiento de su hábitat es una cuestión prioritaria para su conservación en Francia. Se han llevado a cabo numerosos estudios durante varios años que han proporcionado suficiente información sobre el hábitat característico de la rata de agua en Francia, y que nos permite hacer algunas recomendaciones generales en pro de su conservación. La rata de agua se puede encontrar en diversas zonas acuáticas pero siempre con ciertas características en común. En general, las características habituales son la granulometría del fondo del río y su vegetación. La vegetación es típicamente herbácea, generalmente higrófila, y lo suficientemente alta para que las ratas de agua se puedan mover durante el día sin ser vistas. Los ambientes idóneos son frecuentemente aquellos que se mantienen temporalmente en la red fluvial. Estos lugares son a veces inestables debido a perturbaciones naturales o humanas. La distribución local de estos micro-hábitats, su evolución y sus efectos, condicionan en gran medida la conexión y la distribución local de las especies, así como su presencia a través de la red de sitios. Una gran parte de la campiña francesa, en particular las zonas rurales que se mantienen, mantienen su estado en gran medida gracias a la actividad humana. La conservación de la rata de agua en estas áreas depende completamente del mantenimiento de estos sitios como hábitats adecuados para esta especie.

PALABRAS CLAVE: Gestión de márgenes fluviales, corredor fluvial, mamíferos semiacuáticos, red acuática.

\section{LABURPENA}

Arvicola sapidus Miller, 1908 mendebaldeko ur-arratoia espezie erdi urtarra da eta Espainian eta Frantzian bizi da. Seguruenik, mendebaldeko ur-arratoiak gainbehera nabarmena izango du haren banaketaren zati handi batean. Espezie hau Frantzian kontserbatzeko, garrantzitsua da haren habitata zaintzea. Azterlan ugari egin izan dira duela hainbat urtetatik hona eta jada badugu Frantzian mendebaldeko ur-arratoiek ohiko dituzten habitatei buruzko behar adina informazio. Horrek aukera ematen digu kontserbazioan laguntzeko hainbat gomendio orokor emateko. Mendebaldeko ur-arratoia askotariko ur-ingurutan bizi da, baina toki guztiek partekatzen dituzte ezaugarri jakin batzuk. Toki horietan dauden ohiko ezaugarriak, batez ere, ibaietako substratuaren faziesari eta landarediari lotutakoak dira. Lurzoruko landaredia belarkara izan ohi da, gehienetan higrofiloa eta, batez ere, behar bezain garaia, mendebaldeko ur-arratoiak egunean zehar inork ikusi gabe batetik bestera mugi daitezen. Inguru egokienak ibai-sarean luze irauten ez dutenak izaten dira. Toki horiek, batzuetan, ezegonkorrak izaten dira asaldura naturalen edo gizakiek eragindako asalduren ondorioz. Mikro-habitat horien tokiko banaketak, bilakaerak eta lotura-baldintzek, hein handi batean, eragin egiten diote espeziearen tokiko banaketari eta guneen sarean duen presentziari. Frantziako mendi-inguruaren zati handi batean, batez ere landaguneetan, mantentze-lanak egiten dira eta inguru horien egoera giza erabileraren araberakoa da neurri handi batean. Inguru horietan, ur-arratoiaren kontserbazioa aipatu ditugun gune horiek espeziearentzat habitat egoki izaten jarraitzearen mende dago erabat.

GAKO-HITZAK: Bankuaren kudeaketa, korridore urdina, ugaztun erdi urtarra, ur-sarea. 


\section{INTRODUCTION}

The water vole Arvicola sapidus Miller, 1908 is specific to aquatic environments. It can be found in stagnant or slow-running streams, canals, ponds and wetlands, from sea level up to at least an altitude of 2,300 meters. Its world distribution is Iberian-French, limited to a part of the Iberian Peninsula and metropolitan France where it is historically absent from the north-east side of the country (Baudouin, 1984). The water vole has experienced a decline over much of its range of distribution over the last few decades. While it may be a common sight locally, the water vole is, in general, uncommon or rare in France, missing locally, with a great difference between one place and another. This supposed decline is not measurable, and the causes have not been completely identified. It would seem that this is largely due to the loss and degradation of its habitat. To a lesser extent, it could be due to the growing number of exogenous species introduced: mainly the common muskrat Ondatra zibethicus (L., 1766), and probably the wild, brown brown rat Rattus norvegicus (Berkenhout, 1769), and lastly the American mink Neovison vison (Schreber, 1777 ) in certain regions where it lives.

About $40 \%$ of the places where you can find the water vole are located in France, giving this country the important task of being responsible for the conservation of this species in the world. A national survey on the water vole performed between 2008 and 2013 has given us a greater insight into the distribution of this species and the places where it can be found in France. This survey was coordinated by the SFEPM and supported by numerous local centres and/or independent naturalists. It is expected that the results of this survey will inform on the situation of the species. The field-terrain observations already made in a wide range of landscapes of its distribution area as a whole in France have provided us with considerable information about its habitat.

The main points in this article are a direct result of the observations made by the author in different regions, during surveys carried out and field-tests that have not been published. These observations have been amended and contribute significantly to the elements of the National Survey. To this end, this article is complimented by some information from the said bibliography. During the National Survey on the water vole, about 9,500 sections of banks of 100 meters long were surveyed following a defined protocol, in 480 squared areas of $10 \times 10$ km (20 sections per squared area). Each section surveyed has been chosen for it being the most similar to that frequented by the species in the area. For each section surveyed, the presence/absence of the water vole has been detected by signs of presence indicators. This is possible because these characteristic presence indicators are visible after analysis when the water vole settles on the bank; to the contrary, should no signs be detected following exhaustive research this means that there are no water voles in that section. In this way, the habitat of each surveyed section has been researched in a standardised manner.
First, the habitat of the water vole is described at of site of presence level where it is present with emphasis on certain physical habitat conditions required for the species to live there. Then, this description is applied across a section of landscape that constitutes a set of sites inhabited by the water vole with the objective of extending the understanding of the conditions necessary to keep it there. As a result of these two approaches, some general suggestions can be made on how to maintain these areas to promote conservation of the water vole.

\section{MICRO-SCALE HABITAT DESCRIPTION}

The water vole generally lives in several, individual confined groups on a site of a size that does not usually exceed 50 to 200 meters of a long linear environment (waterway, bank of large pond...) or a $5000 \mathrm{~m}^{2}$ surface environment (marshland and water way complex) (pers. obs.; Pita et al., 2010; Rigaux et al., 2009a). The water vole is more demanding in terms of facies than other rodents living in aquatic environments, in particular exogenous species present in Europe: common muskrat, coypu Myocastor coypus (Molina, 1782), and wild, brown rat (pers. obs.). Furthermore, the needs of the water vole seems very similars to those found in France for the european water vole Arvicola terrestris (L., 1758) (formerly A. terrestris terrestris) (pers. obs.; unpublished data). European water vole Arvicola terrestris can be found in the north and north-east of France, in an area to be clarified but whose overall appearance does not match that of the water vole (unpublished data).

At this point, a description of the inherent conditions of the habitat that are required to attract and to keep the water vole on the site is given. This involves a habitat occupied for at least one reproduction cycle by territorial mammals; outside this situation, the water voles could have come into contact on a temporary basis with all types of aquatic habitats when travelling from site to site for diverse reasons (physical disruption of reproduction site habitat, established dispersion, or in search of territory, etc...) (pers. obs.).

The water vole can be found in all sorts of aquatic places, from brackish marshlands on the Mediterranean or Atlantic coast to mountain heath in the Pyrenees. It lives by small streams or on the banks of large rivers, in vast ponds or in a network of small pools, in natural creeks or artificial channels, in certain forest environments as well as farmed countryside and even in urban areas.

Although the water vole can be found in extremely varied aquatic places, it depends upon certain characteristics that are common to all the different types of habitats where it lives. The main requirements of this species are based on the structure of the bank and bank line vegetation as well as certain water regime characteristics (unpublished data, pers. obs.). With regards to other characteristics of the place (physico-chemical, quality of the water...), it would seem that none of these have been clearly identified as being a decisive factor for the water vole to live there and remains to be determined. 


\section{Water}

The water vole needs the constant presence of open water. Some exceptions to this have been found on the Iberian Peninsula (Alis et al., 2009; Fedriani et al., 2002; Román, 2003) are not found in France (unpublished data). When the water disappears from a site (artificial drainage of a pond, natural drying-up of part of the waterway), new indicators about the activity of the water vole could perhaps be found on the site for a short period of time. However, the species staying under these conditions has never been confirmed in France beyond a few days or several weeks (pers. obs.).

The depth of the water in the different occupied areas is diverse, but rarely lower than $10 \mathrm{~cm}$. The flow of the water can be non-existent or slight. It is not known what measure could be applied here but it is quite clear that water voles do not inhabit a site where the water flow is too strong inhibiting viable water activity. These animals make a burrow in the bank where the entrance is normally above water from which they can easily swim. Water voles have been found to inhabit areas of moderately fast flowing water if there are frequent intermittent micro-areas of calmer currents. The mammals that inhabit this type of site are usually found in these micro-areas. It is assumed that they could move between them over land using the banks that run alongside the more strongly running currents.

\section{Structure of vegetation coverage}

The settlement of the water vole on a site is dependent on the presence of an herbaceous vegetation cover, thick and perennial on the immediate edge of the water. This cover must be along a strip of at least 30 to $50 \mathrm{~cm}$ from the outer edge of the water. It must also be at least $30 \mathrm{~cm}$ tall. This characteristic seems to be extremely important. The water vole must be able to move around under the shelter of this cover. The need for this sheltered movement is due to the real need for protection against predators (Graells, 1897; Román, 2003). In the natural environment in France, a site inhabited by water voles where the embankment does not give some form of partial cover allowing for the sheltered movement of the water voles on the surface is not known of (unlike the Norway Rat or the Coypu or even the Musk Rat who might suffice with bare banks or cropped vegetation (unpublished data). The water vole also feeds on this vegetation.

At site level, the facies of banks over one meter high from the water do not appear to have any determining influence over their presence. There is evidence of this for example where the same stretch of river passes through agricultural areas used for a variety of purposes, woods and even urban areas: the water vole can inhabit suitable sections regardless what the general environment is beyond the banks. This is the case in many of the rural landscapes in France. You can even find the water vole at a very local level in certain areas of large-scale intensive cereal farming. In this case, the species cannot be present if the waterway itself and its immediate banks do not have a sui- table facies of some 10 centimetres in width. This exists for example in the Paris Basin, on the cultivated plains of Auvergne or in the south-west of France. It would seem, however, that the species is scarce in these landscapes and in most cases non-existent. The reasons for this absence could be examined from a larger landscape perspective rather than the proximity of the inhabited area and its adjacent land (pers. obs. ; unpublished data).

The density and the length of cover provided by vegetation of a few tens of centimetres or metres from the water's edge seem to have a positive influence over the water vole staying for a medium term. In addition, the vegetation cover is even more suitable if is in direct contact with the water. To the contrary, the predominance of bare or open ground for several tens of centimetres long between the water and the vegetation is adverse to species installation. However, it could happen that the species stays to a certain extent on a site where the facies are growing: for example, when the water level lowers in a pond and reveals an area with bare ground between the river water and vegetation. But their stay is more often temporary (pers. obs.).

\section{Composition of vegetation coverage}

A suitable site where the water vole is likely to settle is where the vegetation right on the edge of its banks is herbaceous, and in general hygrophilous. Its botanical composition does not appear to have any influence over the presence of the water vole in terms of food. This is quite evident when observing their "refectories "; small eating places where the water vole leave plant fragments that is cut up (pers. obs.), and confirmed by some surveys performed on the mammal's diet (Fabien, 2000 ; Garde \& Escala, 2000): all of the herbaceous species growing on the banks throughout the year are eaten as well as the soft above-ground plants that are accessible close to the ground. Nevertheless, it is likely that the water vole is attracted by the above-ground plants with aerial parts still appent during the winter months, such as the rush (Juncus sp.) (pers. obs.).

The botanical diversity of the bank's herbaceous coverage does not seem to have any influence over the water vole. A lack in specific richness does not seem to be a limiting factor either; in the case of certain singlespecies rush (Juncus sp.) in which the density of the water vole could be high (Grasset, 2011; obs pers.). This could be explained by the fact that the presence of certain species of plants is conducive to maintaining the water vole due to the structural role that they play. These plants are suitable because they are high enough to cover the water vole, being thick, and stable throughout the year (in the case of rush Juncus sp). Conversely, in the summer, herbaceous vegetation offers an attractive shelter but its structure is not so attractive to the water vole when it changes during autumn and the winter months making it an unsuitable habitat. This could perhaps be the case for vegetation that is composed of certain sedge (Carex sp.) that is tall in the growing season but collapse completely in the autumn, inhibiting the mo- 
vement of the water vole over land. The opposite is true for vegetation that is enough tall during the spring-time growth that flattens during the winter months being less suitable medium-term than vegetation offering more stable coverage throughout the year (pers. obs.).

To a lesser degree the water vole can be found on sites where the vegetation coverage right on the river banks is partially ligneous (unpublished data). This vegetation type is suitable because its lower layer is thick enough for the water vole to move around underneath. It could have thorns being part of the bramble (Rubus sp.) or a bushy variety close to the ground. This type of vegetation however is not enough to attract the water vole because it is not something that it eats, or very rarely. Some distinct eating habits exist: for example the water voles feed on willow-genus branches Salix sp. when there are no herbaceous plants available during the winter months on a frozen pond (pers. obs.). Overall, to make the site viable, if the bank's vegetation is partially ligneous, it must be sufficiently abundant to guarantee the food source. This twofold requirement in terms of vegetation (structural coverage/food source) is found in an edifying way in some marshland where the vegetation is primarily composed of woody Salicornia (Arthrocnemum sp., Sarcocornia sp.). In this marshland, the vegetation layer close to the ground takes the form of a thick, bushy coverage at the water's edge giving the water voles a shelter that is not very attractive as such. On the other hand, the tip of the salicornia branches is herbaceous and clearly appetising. These branches grow in abundance very close to the ground and are therefore accessible. In this way, the juicy parts of these branches are abundantly eaten by the water voles up to the point that they form the main source of their food supply and can be seen in their "refectories".

\section{Structure of the bank}

The need for the water vole to dig a dry burrow in the bank with an entrance that is quite often underground means that the bank must have certain characteristics or type of waterside substratum: the latter must be sufficiently soft but firm and be at least $15 \mathrm{~cm}$ above water level so that the burrow keeps dry. On the other hand, a bank that is too high or steep would not be suitable because the water vole would not be able to move around or stand right on the edge of the river bank. This criterion is linked to the importance of the presence of a vegetation coverage that guarantees free movement on land and facilitates an interface between water and land.

However, it has been known for the water vole to inhabit sites where the bank is high and with no vegetation right on the water's edge. This situation occurs when the bank has a solid sub-surface; that is, when the lower part of the bank has a culvert that forms a large niche in a straight line like a sheltered corridor at the water's edge. This rather particular bank structure allows the water vole to move on land along the water's edge, whilst being camouflaged by the sloped edge of the bank making up for the lack of vegetation coverage where the land meets the water. In this situation, their food source is found above the edge of the bank. If these plants are not accessible or scarce to non-existent, the site would not be a suitable habitat for the water vole (pers. obs.).

In swamp areas, where there are no banks, water voles might still build their nests. They could settle in the vegetation where it is sufficiently thick, dense and solid to form a substratum that would be like the ground of a bank. This would be the case for "tussock" facies that are hillock-type structures made by sedge Carex spp. growing in dense mounds. This is also common to reed beds in which the water vole can build a nest hidden amongst the reeds and lying on a heap of plant debris or any type of substratum that is not covered by water. This nest is the shape of a ball made out of plant debris of about $30 \mathrm{~cm}$ in diameter. Nonetheless, this type of nest installation is not very common (pers. obs.). Above all, marshland does not have any type of substratum that facilitates the making of a sheltered nest and the water vole cannot build a habitat out of the water.

\section{Conclusion: the four requirements of the water vole}

The structural conditions required for the water vole to settle on the site can be summarised into the following four points:

- open water facilitating under water swimming (exceptions excluded)

- physical coverage between water/land allows sheltered land movement

- appropriate substratum for building a nest right on the water's edge

- accessible herbaceous vegetation to eat

Obviously the aforementioned requirements are not an exhaustive description of the structural conditions needed so that the water vole settles on the site and should be viewed as its vital domain in order to stay. In this way, to make up a suitable habitat, the bank facies may not be on ground level all of the time or cover the entire land mass normally inhabited by a group of these mammals but must be predominant on the site.

\section{HABITAT DESCRIPTION AT THE LANDSCAPE LEVEL}

At the landscape level, a suitable habitat for the water vole rarely exists all the way along the water system catchment area. There are only certain places, very specific and very limited, that have a suitable and continuous habitat over a long distance or large surface area. This is the case, for instance, of the old man-made drainage ditches on the l'île de Noirmoutiers, in Vendée: these ditches are edged with a thick covering of rushes several kilometres in length. There is a continuous presence of the the water vole in this area (Grasset, 2011). To a lesser extent, this is the case in other marshland, and in particular coastal 
marshland on the Atlantic and Mediterranean coasts. Here, the habitats appears to be suitable continuous across large surface areas however this does not mean that the water vole is common. More often, it is not even found at these sites and is rather scarce with irregular sightings and frequently absent.

\section{A network of interconnected sites}

Often, a suitable habitat for a water vole is only available at certain points along the water course system. At times these places can be clearly and easily identified in landscapes with water course systems if the sections are differentiated making their habitat easy to characterise. For example, in the case of some of the long, mid-mountain rivers in the Alps. These streams for the most part have an appearance of vast gravel shores on which the water vole could not settle, whereas he only settles in some confluences. Petits annexes hydrauliques provide a very suitable facies, completely different to that of the river itself (Rigaux, 2013a). In terms of length, they make up a small portion of the local water system catchment area. The river connects them enabling the water voles to colonise them. This network of macro-sites keeps the population alive along the points of the river basins (pers. obs.).

\section{An unstable network due to human activity}

In many of the landscapes in France, the facies of the embankments right on the water's edge is largely related to human activities: mowing, crushing, grazing, scrub clearing, etc. This is the same for the majority of rural landscapes and in particular for the smaller streams. Yet the majority of water vole populations in France are very likely to be found in rural spaces. Human activities as a whole as well as historic development of these rural spaces have clearly influenced and are still influencing the local distribution of this species. The understanding of how water vole populations work in connection with human activity is particularly significant for the conservation of this species.

When a site occupied by the water vole experiences an upheaval to the extent that the habitat is destroyed, the water vole usually abandons the site in the short term. Its habitat could be damaged in such a way that one of the aforementioned facies disappears. This is the case for example when the vegetation right on the banks is cut too close to the ground and the water vole can no longer move in a sheltered area (pers. obs.; Rigaux et al., 2009b). These upheavals are usually linked directly to human activity on the banks or driven into the stream (mowing, grazing, clearing....). It could also be independent to direct human activity (flood, drought...). These disturbances can result in a temporary change (waiting for the vegetation to grow back the following year) or can result in a more lasting change (physical change to the river).

In the same way, sites can be abandoned when the habitat does not evolve in a satisfactory way for reasons relating to the lack of human pressure (mowing, grazing). As a result, the lack of intervention can, in certain cases, lead to, in the medium to long term, the development of woody vegetation making the herbaceous vegetation close to the ground disappear: development of bushes, brambles Rubus spp. Small irrigation or drainage channels abandoned by farmers could make the habitat less suitable to the water vole (pers. obs.; Bonnet, 2006 ; Rigaux \& Charruau 2007).

It has been observed that sites abandoned after undergoing an upheaval of facies (mowing, clearing) can be colonised once again one or several years afterwards, because the other nearby sites with a suitable habitat welcome the species. These nearby sites are of course refuges (Rigaux et al., 2009b). Temporary sites can only accommodate a handful of mammals because the in relieable on smalls, linears zones. In general, these sites are only inhabited if there are other, suitable sites nearby and that they are connected by a water network. These interconnected sites are usually less than $3 \mathrm{~km}$ apart along the water network and very rarely exceed 10 km. (pers. obs.).

At times, the distance between habitats and their distribution can be clearly identified in rural landscapes. When a small stream runs through a multitude of agricultural land, the facies is extremely variable according to the different plot of land and the different farmers concerned. This variety is due to current actions or actions in the past that have affected the banks: mowing (or not), frequency, installation (or not) of an electric fence to stop the cattle accessing the stream and subsequent tramping, etc. River-side farmers, without knowing it, could condition their actions with regards to the the local distribution of the water vole (Rigaux \& Charruau, 2007).

\section{An unstable network due to natural causes}

This network organisation of unstable, inter-connected sites can also be found in places where there is no human activity. A river is known for being an important, dynamic waterway and is a case apart for causing instability in the habitat of the water vole in a natural way. Rivers where the current and the facies are continually being reclaimed by floods, sections of the suitable habitat disappear, while others just disappear over time. For example, a flood could create a secondary channel to the slow-running current in which sediment settles and by consequence herbaceous vegetation starts growing on the banks. On the contrary, sections of the suitable habitat are continually being wiped out by floods that strip away the vegetation. This can be seen in the rivers in the vicinity (approach) areas of the Alps, or sometimes in the Loire in the centre of France. In these places, it is recognised that the local populations of the water vole is due to the sustainability of the site network, even if each site is highly unstable (pers. obs.).

Unstable sites can also be found in certain river systems that have dried up in part during the summer months. This is the case of Maures, a vast forested area 
to the south-east of France in the Mediterranean. Here the river system is such that the streams practically dry up for several months of the year. Under these conditions, during the summer, the water voles seek refuge and stay on a temporary basis in the micro-sections of the river network where there is still some open water. These micro-sites are natural basins that hold water edged by vegetation. Throughout the rest of the year when the water is wide spread across the river system, the local distribution of the water vole is very different (and more difficult to characterise). What does seem to be clear is that at a very specific landscape level, the presence of a water vole population depends on the existence of open-water refuges (pers. obs.).

\section{Conclusion: distribution of the water vole in the landscape}

The water vole has a certain ability to adapt to the temporary nature of its habitat. This is very likely to be related to two key facts: the water vole is completely dependent on its habitat and this habitat does not always exist in a way that is long-standing and sustainable.

The most common spatial organisation of water vole populations in French landscape where the species can be found can be described in the following three points:

- On random sites on the edge of a stream, pond, or marsh where the water vole can be found along the banks that are about a few dozen to a few hundred metres.

- Sites that are inter-connected and usually distributed over a radius of a few kilometres in such a way that they form "isolated populations" some being on lower (2 to 3) or higher sites.

- Site occupation is usually stable if there are no disturbances, but there could be a spatio-temporal variability over the years within these isolated populations due to human activity and/or natural circumstances that could compromise the habitat of the species.

In most cases, a linear waterway occupied by the water vole with isolated populations is a minority. This apparent low population count may be explained due to the lack of suitable habitats available along the waterway; this could be related to human activity, or not. In other cases, the habitat does not seem to be a limiting factor and the low population count is inexplicable. Furthermore, in between these isolated populations, there are often vast areas where the water vole cannot be found. The absence of the water vole in these isolated populations cannot always be due to not having a suitable habitat.

This organisation is confirmed by the observations and land surveys carried out in different regions in France where the species can be found (pers. obs.; unpublished data), even if very little bibliographical material is available (Rigaux \& Charruau, 2007; Noblet, 2008; Barré, 2009; Legrand, 2009 ; Rigaux \& Charruau, 2009; Hervieu, 2011; Pellegry, 2011; Sorrel, 2011; Rigaux, 2013b). Numerous studies on the water vole, carried out with more effective means (genetic) in the Iberian Peninsula also confirm this
(Fedriani et al., 2002; Centeno-Cuadros et al., 2011...). Above all, there is a strong similarity on what is known about the water vole (Arvicola terrestris) in England (Stratchan \& Moorhouse, 2006...).

\section{PRESERVE THE WATER VOLE IN THE LANDSCAPE}

In natural areas where the habitat is suitable for water voles and is sustainable independent to human activities, it goes without saying that it is recommended that they should not be disturbed to ensure the conservation of this species. These places could be sections of water ways, marshland, or bogs, or different types of wetlands. If, however, human activity has to be performed on these places, it is essential that the sections where there is a suitable habitat for the water vole are conserved.

When the existence or the sustainability of the habitat is directly linked to human activities, its preservation must be comprehended at both site and landscape level (or network of sites).

To make sure that the water vole stays on the site, it is important to foster stability and, in particular, herbaceous vegetation coverage at the water's edge. This vegetation must be kept sufficiently high and long-lasting. In pasture areas, the conservation of the habitat could be made better if the cattle were kept one metre away from the water to stop them stamping the ground and/pulling up such important vegetation. Herbaceous vegetation beside rivers must only be cut if there is a medium-term requirement because there is a natural scrubland cycle. Maintenance must be performed preferably outside the reproduction period of the water vole, namely October through February.

At landscape level, this means there is always the possibility that there exists a network of suitable sites. In this way, when the habitat of the water vole is destroyed along a section of the bank, it is imperative that other sections of the bank are preserved close to the affected site. If actions are performed at the level of the river network as a whole or on its banks (mowing, crushing...), it is important that they are carried out in sections, leaving sections untouched each year to serve as a refuge for the water voles.

It could be said that this approach is a natural process in certain landscapes in France. This maintenance is performed in an uncoordinated way and it is quite obviously done without any intention to preserve the water vole species and unwittingly helps the water vole in a positive way. This is particularly apparent in small streams and channels in breeding areas in many regions. In general, farmers with river plots of land are not aware of the existence of the water vole but their actions could be beneficial in the medium-term. If the farmers cut the banks every now and then to stop them becoming overgrown this could help preserve the habitat of the water vole. If these actions are not performed along the local river network the same year, a group of suitable sites continue to be permanent and enables the species to stay (Rigaux \& Charruau, 2007; Rigaux et al., 2009b). 
On the contrary, certain actions are harmful on the short-term: burning of bank vegetation over large areas, general clearing, etc. It has been confirmed that the water vole disappears after a certain degree of disturbance to their habitat at the level of the river network as a whole even if there are few random, more isolated bank sections with suitable habitats. The level of intensity that causes this disappearance is difficult to evaluate in the sections where human activities on the water's edge is relatively moderate but is very clear in areas of high activity where the activities along the waterway and banks are intense. In many of these landscapes, it is quite obvious that the pressure of human activities is such that the water vole's habitat no longer exists: radical transformation of the waterway, concreting of banks, continuous clearing, and destruction of wetlands, etc.

The impact of these human disturbances on the habitat of the water vole also affects other elements of the vegetation coverage: physical structure of the banks, artificial variations in the level of the water, etc. Nonetheless, the impact of these human actions on river vegetation seems to be affecting many French landscapes and is one of the main factors that has a direct influence on whether the water vole settles and the density of the subsequent colonisation.

The water vole is by nature absent from rather large areas where the river network is not a suitable habitat due to natural circumstances (rocky banks, forestation, unsuitable river network...). Elsewhere, the historic degradation and regression of wetlands in France are without doubt factors that have influenced local decline and disappearance of the species. It is highly likely that the absence of the species in large areas in France is due to the indirect or direct impact of human activities on the river network. In the areas that are currently populated, the loss of its habitat due to the harmful activities by humans along the waterway seems to be an important factor that threatens water vole populations. Taking into consideration the water vole's habitat seems to be one of the main initiatives to put into place in order to preserve this species.

Even so, is it really necessary that precise conservation measures be implemented to conserve the habitat specific to the water vole? This would involve close management specific to waterways and their banks with the objective of preserving or creating suitable places for this species. It would seem that such measures have shown their ability to preserve the water vole as part of a Restoration Plan in England where the state of conservation of the water vole was critical (Stratchan \& Moorhouse, 2006). To establish more stronger protection of water areas policies. It is perhaps not necessary to put into place a specific maintenance system orientated towards the precise, ecological requirements of this species, if the waterways, their banks and the water places are better protected on a global basis. The water vole was inscribed in 2012 on the French list for protected mammals in France just as nearly all native semi-aquatic animals in the country have been gradually inscribed over time: the European beaver
Castor fiber L., 1758, European otter Lutra lutra (L., 1758), European mink Mustela lutreola (L., 1761), Eurasian water shrew Neomys fodiens (Pennat, 1771) and Southern water shrew Neomys anomalus Cabrera, 1907. It is hoped that statutory protection of the water vole is a starting point for possible actions in favour of the protection of continental aquatic areas in France benefiting the water vole itself as well as the ecosystem as a whole.

\section{AKNOWLEDGEMENTS}

A big thank you to all the group of people, naturalist associations and different centres that have contributed in one way or another to the knowledge and protection of the water vole in France. Special thanks to: Groupe Mammalogique d'Auvergne, Groupe Mammalogique Breton, Groupe Mammalogique Normand, Groupe Mammalogique et Herpétologique du Limousin, Groupe d'Etude des Mammifères de Lorraine, CPIE Gers, CPIE Oise, CPIE Collines normandes, CPIE Brenne, PIR Marais Poitevin, PN Ecrins, PNR Landes de Gascogne, PNR Anjou-Touraine, PNR Monts d'Ardèche, CREN Aquitaine, LPO Champagne-Ardenne, LPO Aveyron, LPO Anjou, LPO Franche-Comté, LPO Provence-Alpes-Côte d'Azur, LPO Charente-Maritime, LPO Drôme, LPO Vendée, Mayenne Nature Environnement, Sarthe Nature Environnement, Nature Environnement 17, NaturEssonne, Nature Midi-Pyrénées, Picardie Nature, Vienne Nature, Perche Nature, Nature 18, Deux-Sèvres Nature Environnement, Naturalistes Vendéens, Charente Nature, Sologne Nature Environnement, Loiret Nature Environnement, Eure-et-Loir Nature, Loir-et-Cher Nature, Naturalistes de ChampagneArdenne, Haute-Saône Nature Environnement, GREGE, SEPANT, SEPANSO, Lot Nature, Gard Nature, Cistude Nature, Centre ornithologique d'Île-de-France, Association lozérienne pour l'étude et la protection de l'environnement, Société d'histoire naturelle d'Autun, RNN Courant d'Huchet, RNN Marais de Bruges, RNN Etang noir, RNN la Mazière, RNN Grand-Pierre-et-Vitain, RNR Polder de Sébastopol, Maisons de la Loire du Loir-et-Cher et d'Indre-et-Loire, CORA Faune Sauvage, FRAPNA, Réseau Mammifères ONF, AAPO Pont de Gau, F. Poitevin, C. Riols, D. Beauthéac, P. Charruau, M. Chalbos, F. Auvity, S. Trouillet, E. Braure, C. Marinosci, C. Dupasquier, M. Georgeault, E. Mirouze, L. Halliez, R. Barbance, C. Bouit, B. Collet, C. Roubinet, J. Maguin, Y. Lebecel, M. Batista, F. Landré, D. Pagès, S. Boursange, C. Arthur, D. Pain, G. Abadie, V. Toussaint, C. Favier, M. Bertilson and to all contributors to the national survey as not all of you can be mentioned here.

\section{BIBLIOGRAPHY}

Alís, S., Narváez, M., Rivilla, J.C., Román, J. 2009. Distribución y abundancia de la rata de agua (Arvicola sapidus) en las provincias de Sevilla, Cádiz y Huelva. IX Jornadas Españolas de Conservación y Estudio de Mamíferos. Bilbao (Póster).

Barré, K. 2009. Evaluation des potentialités d'accueil du water volesur la partie amont du bassin versant du Couasnon: état des 
lieux, diagnostic et propositions de gestions. Syndicat Intercommunal pour l'Aménagement du Couasnon, rapport de stage de BTS GPN

Baudouin, C. 1984. Le campagnol amphibie Arvicola sapidus. In: Atlas des Mammifères sauvages de France. A. Fayard: 162163. Société Française pour l'Etude et la Protection des Mammifères, Paris

Bonnet, X. 2006. Répartition et sélection de I'habitat du Campagnol amphibie, Arvicola sapidus, sur le domaine de la Tour du Valat. Rapport de stage.

Centeno-Cuadros, A., Román, J., Delibes, M. Godoy, J.A. 2011. Prisoners in their habitat ? Generalist dispersal by habitat specialists: a case study in southern water vole (Arvicola sapidus). PLOS ONE 6(9): e24613. doi:10.1371/journal.pone.0024613.

Fabien, L. 2000. Impact du Campagnol aquatique Arvicola sapidus sur la végétation à la source de Cressenval (76430). Université du Havre, Faculté des Sciences et Techniques. Rapport de stage.

Fedriani, J.M., Delibes, M., Ferreras, P., Román, J. 2002. Local and landscape habitat determinants of water vole distribution in a patchy Mediterranean environment. Écoscience 9: 12-19.

Garde, J.M., Escala, C. 2000. The diet of the southern water vole, Arvicola sapidus in southern Navarra (Spain). Folia zool. 49 (4): 287-293.

Graells, M.P. 1897. Fauna Mastodológica Ibérica. Mem. R. Ac Cienc. Exactas Fís. Nat. XVII: 504-506.

Grasset, V. 2011. Répartition et exigences écologiques du Water voleau coeur de la RNR du polder de Sébastopol. Réserve naturelle régionale du polder de Sébastopol. Rapport de stage de BTS GPN.

Hervieu, F. 2011. Le Water voleet la Crossope aquatique sur un secteur de marais confronté aux espèces invasives - ENS des Ponts d'Ouve - Manche. Espace Naturel Sensible des Ponts d'Ouve. Rapport de stage de BTS GPN

Legrand, N. 2009. Etude sur les exigences du Water voleArvicola sapidus en termes d'habitats sur la partie limousine du PNR Périgord-Limousin. Groupe Mammalogique et Herpétologique du Limousin. Rapport de stage de Master 1.

Noblet, J.F. 2008. La situation du Water vole(Arvicola sapidus) dans les Alpes-de-Haute-Provence - France. Nature \& Humanisme, rapport d'étude.

Pellegry, T. 2011. Le water voleArvicola sapidus au Bioparc Zoo de Doué - Analyse des effectifs, de la répartition de la population et conséquences sur la gestion du site. Bioparc zoo de Doué la Fontaine/Université Bordeaux 1. Rapport de stage de Master 1.

Pita, R., Mira, A., Beja, P. 2010. Spatial segregation of two vole species (Arvicola sapidus and Microtus cabrerae) within habitat patches in a highly fragmented farmland landscape. Eur. J. Wildl. Res. 56: 651-662.

Rigaux, P., Charruau, P. 2007. Le Water voleArvicola sapidus dans le bassin versant de la Sioule (Allier, Puy de Dôme et Creuse). Etat de la population, influence de facteurs naturels et anthropiques et apport général à l'étude des populations. Groupe Mammalogique d'Auvergne. Rapport d'étude.

Rigaux, P., Charruau, P. 2009. Eléments pour l'étude du water vole (Arvicola sapidus) et des facteurs de sa répartition. Exemple du bassin versant de la Sioule (Allier, Puy-de-Dôme, Creuse). Arvicola 19 (1).

Rigaux, P., Chalbos, M., Auvity, F., Braure, E., Trouillet, S. 2009 (a). Eléments sur la densité locale et l'utilisation de l'espace du water vole(Arvicola sapidus): exemple de trois sites en Auvergne. Groupe Mammalogique d'Auvergne. Rapport d'étude.
Rigaux, P., Chalbos, M., Auvity, F., Trouillet, S., Christianne, L. Bartalucci, A.L., Braure, E. 2009 (b). Trois années de suivi du Water vole (Arvicola sapidus) dans le bassin versant de la Sioule (Allier, Puy-de-Dôme, Creuse). Groupe Mammalogique d'Auvergne. Rapport d'étude.

Rigaux, P. 2013 (a). Inventaire du Water vole(Arvicola sapidus) et éléments de préconisations de gestion en faveur de la conservation de l'espèce dans le cadre de travaux de restauration sur quatre adoux de la haute Durance (Hautes-Alpes). Ligue pour la Protection des Oiseaux Provence-Alpes-Côte d'Azur. Rapport d'étude.

Rigaux, P. 2013 (b). Répartition de la Loutre d'Europe (Lutra lutra), du Water vole (Arvicola sapidus) et du Castor d'Eurasie (Castor fiber) en Provence-Alpes-Côte d'Azur. LPO PACA Faune-PACA Publication n`35.

Román, J. 2003. Hábitat y hábitos de la rata de agua (Arvicola sapidus) durante el periodo de sequía estival en Doñana. VI Jornadas de la Sociedad Española para la Conservación y Estudio de los Mamíferos. Ciudad Real.

Sorrel, D. L. 2011. Les espèces de Campagnols du genre Arvi cola en Aquitaine: Éléments de connaissance sur leur répartition et leurs habitats. Cistude Nature/Université de Montpellier 2. Rapport de stage de Master 1.

Strachan, R., Moorhouse, T. 2006. Water vole conservation handbook. Environnement agency, Wildlife conservation Research Unit. 